\title{
COMMERCIAL EVOLUTION OF WATERFRONT: A HISTORICAL ANALYSIS OF LAND USE PATTERN \& TREND OF COMMERCIAL CENTERS IN KHULNA RESPECTING BAROBAZAR, KHULNA
}

\author{
MUHAMMAD GOLAM SAMI ${ }^{1} \&$ SHAUNI PRIYAM SIKDER ${ }^{2}$ \\ ${ }_{1,2}$ Department of Architecture, Khulna University of Engineering \& Technology, Khulna, Bangladesh \\ ${ }^{1}$ sami1625007@stud.kuet.ac.bd, 2shauni.29arch.buet@gmail.com,shauni.sikder@arch.kuet.ac.bd
}

\begin{abstract}
Although Khulna's actual history is not about more than 200 years, but it has a 2000 years settlement and commercial history. Khulna was a part of Ganaridai, Vanga, Jessore dynasty, Rarh (South Bengal) in different periods. The connection of rivers always made a blessing for Khulna for water transportation to accelerate trade and commerce. According to Ptolemy, the ancient Gangaridai had an ancient port located in greater Jessore [1,557]. Some archaic incidents, verses, and legends of Mani-Rishis (Ancient Indian Scholars) proved the old settlement and commercial style. The chronological evolution of the ancient Period ( $6^{\text {th }}$ century BC $-1757 \mathrm{AD}$ ) described a civilization's development with the incremental commercial approach [2,315]. The colonial regime can relate to the evolution of a commercial and economic center like Barobazar as a whole. All these chronological narrations, consecutive phenomena, and influential factors will depict the trend of retail evolution. The research aims to describe Khulna's commercial development's sequential affairs and find the missing links between eras. Various ancient documents, Blueprints, Greek Periplus, etc. will describe the settlement, commercial mode, and history. It will determine the answer to the questions about the growth and establishment of river port cities and major economic centers' evolution. The paper will describe commercial -spatial progression in 4 Particular eras. GIS surveys and some old maps will illustrate the commercial land-use patterns of Barobazar from the Colonial Period to the present and the river base trade. These will elaborate on the existing conditions as well as the revolutionary changes. The fundamental research will help for the further Urban regeneration of Barobazar as a central economic hub. The historical consequences will help to sort out the development pattern and strategies behind the progression.
\end{abstract}

Keywords: Commercial Evolution; Historical Chronology; Trend in Commercial Development; Economic Major Hub; Commercial Land Use.

\section{Introduction:}

The Khulna is the third-largest metropolitan city in Bangladesh, with 1.2 million populations within 45.6 square kilometers (Ahsan 2012). It is a city of riverports (ghats), and it is also served by the second-largest seaport (Mongla) in Bangladesh. Historically Khulna was a part of Vanga or Samatata, Sultanate of Bengal, Baro Bhuyans \& Mughal Emperor. During the Colonial Period, firstly, it was under the rule of autonomous nawabs (rulers) of Bengal until 1793, when the British East India Company abolished Nizamat (local government) and took control of the city. [3]_Though there is no reliable information on the trade of Khulna during the Mughal Period. There are some documents about the salt trade, but it cannot tell the whole scenario. River Bhairab was a lifeline for water transportation owing to trade and commerce for the ancient Period. Due to the fertile land upon the shore of river Bhairab different settlements have also developed, and many antique markets also evolved in its continuity. During the colonial regime, a massive transformation in trade happened due to different influential factors such as river ports, the Creation of Rupsa, New communication development.[2,985]. These phenomena influenced waterfront base economic and commercial growth respecting Barobazar during the Colonial Period. (Ahsan,2012). Later, due to the rapid development of communication and infrastructural transformation, Barobazar is the major economic hub in the southern part of Bangladesh. As the rapid urbanization has taken place at Barobazar due to different influential factors and multiple actors at independent Bangladesh, rapid commercial land use pattern changes are the reason. This research will critically analyze the historical evolution and multiple factors regarding the commercial state of Khulna and the changes in land-use patterns, and the current trend of Barobazar. We will explore the Spatio-temporal prominence of the land use pattern in 4 distinctive sections- Early Colonial Period, Colonial Period, Pakistan Period \& Independent Bangladesh period. The socio-political scenarios of the early '8os have created an influential-changes in the demography and physical environment of Barobazar. 


\section{Early Colonial Period: $6^{\text {th }}-$ century be to 1757:}

Evidence of the first settlement in Khulna is found in the early Hindu Period. Some of its descriptions are known from ancient verses and the legend of Mani Rishi. We do not know much about Anaryans (Pond, Chandal, Bagdi) as they had no specific religion and food habit. However, the first Aryan settlement has happened in $6^{\text {th }}$ century BC via water transportation. Among Aryans castes, first Kshatriya (Warrior) Aryans invaded the "Vanga" (Bongo), then Vaishyas (Businessmen) came here for business purposes. Brahmins come at the end of all to preach the religion. Moreover, there also established some pilgrimage in Ancient Khulna. The south part of Bengal was considered a part of ancient Vanga, and the subdivision was called Rarh. [2.327]

A. Commercial state and trend in Ancient Khulna: We heard about the large boats on the rivers as a medium of large water transportation by Indo for the Aryans. Nevertheless, actual commercial state-run after the Aryan Vaishyas had come here in Vanga, they introduced internal trade within the Indian Subcontinent considering Vanga. Before that Anaryans water transportation medium was a small boat called "Bachari", we heard about the salt business from the sea surrounded Sundarbans. Salt factories (Vand) were called "Molonga," and salt producer was called "Molongi". This salt business ware progressed by Aryans. The transported salt from Sundarbans to other states via the river network.[2,329]

B. Ganga Ridai and the Oldest Port: According to Greek ambassador Megasthinis (who was at Morya Chandra Gupta's Rajsava), Jessore and Khulna were called Ganga Rashtro or Ganga Ridai or Ganga Radi. Gangey / Gangarejia is considered one of the principals and oldest commercial port of the Indian Subcontinent (located at the old Jessore, Not current one, according to Pareshnath Banarji). Greek "Periplus of the Erythrean Sea." The first possible international trade had been heard in this Period. The river channel of the lower Ganges influenced Gangarejia. The port was famous for exporting Maslin, Coral overseas.(The southern part of Calcutta towards the sea was familiar as a coral island for the abundance of coral). [2,327-328]

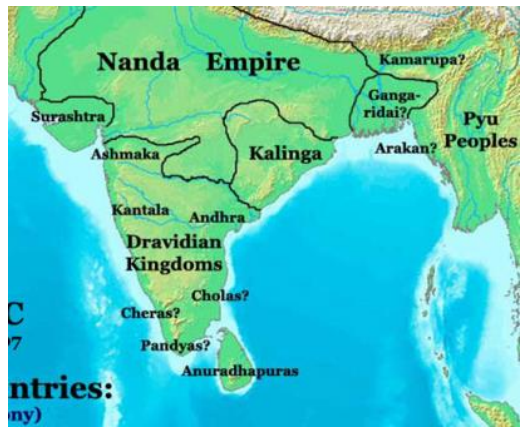

Fig. 01:East Hemisphere, Map of Ganga Ridai -323 bc [4]

C. Shena Dynasty (120oAD): In ancient Khulna, Sundarban was familiar as "Dwiganga." Due to Sundarbans' ups and downs, Shenas came to Barishal and Khulna area and established at RayerKanthi and Bangram. They had established some settlements within the bank of river Bhairab. Shener Bazar at Aichgati, Belfulia is considered as an ancient market established in Shena dynasty. It is believed that several local haats (village market) had been established in that Period within the riverport support and water transportation system.[2,355]

D. Muslim Period(1301 AD-1793AD): The first Muslim arrived at ancient Khulna in the 12th or 13th century $\mathrm{AD}$. In 1301 Khulna came under the independent Muslim Sultanate of Gauda. Later, Khan Jahan Ali, Hussain Shahi, Pathans, Vikramaditya, Pratapaditya took the control. Vikramaditya was defeated by Man Singh I, a Hindu general of the Mughal emperor Akbar, in 1611. [2, 751]

Commercial state of Bengal Sultanate: According to Irfan Habib (2011), Ma Huan's testimony described the shipbuilding Industry in the Bengal sultanate. Co-existed Bengali ships with Chinese in 
the Mid-15 $5^{\text {th }}$ century in the Indian Ocean, according to the testimony of European travellers, also supported that.

\section{Influential Commercial Trend in Khulna Regarding Sultanate:}

According to Satish Chandra Mitra, Khulna had a trend for commercial Boat factories ( Because of the adequate supply of wood from Sundarbans). The sea surrounded Sundarbans had enough possibilities for an establishing port like Gangey in the ancient Khulna. Even though the Salt business was continuing in Nawabis and also in Sultanate. Bhairab had a history of commercial water transportation also. Some ancient markets besides the Bhairab river bank also run in that Period. Khulna, specially Sundarban, may have a commercial trade relationship with overseas like Maldives and China (Wang,2017). Among all exported ingredients, Muslin, Rice, coral \& Coconut had exported from the south Bengal. (Sushil Chaudhury,2012) Above all, in ancient Khulna, the maritime trade, the rivers' connection, and the abundance of exportable goods encouraged the Company to establish a trading center later in the colonial era.[2,442,483,493]

Socio Economical Dark Era: Mugs \& Firingis: The Portuguese (Firingis) started coming to South Bengal for trade in the first half of the 18th century. Despite their exclusive rights to the Sundarbans salt trade, they are involved in human trafficking. Later in 18s, Shaista Khan expelled the Mugs and Firingis from the south. So, these fifty years is considered a black chapter in the southern region's trade. [2,627]

The settlement \& the commercial trend at the riverbank of Bhairab from the ancient era to Autonomous Nawab: Due to the rise and fall of the Sundarbans, the Sen dynasty of Gangarejia moved upwards and settled on the banks of the Bhairab. The land upstream of the river helps them to expand their agriculture. Sen's market at Aichgati in Belfulia is considered to be of that era. Besides, it is known that many more hats and bazaars were established on the banks of Bhairab. Agricultural products were significant in the commercial field. Cotton and paddy cultivation are especially known. Bhairab bank had become a commercial center and river port later. The commercial style of ancient Belfulia is seen as one reason for the development of the Barobazar on the other side of the river.[2,394-396]

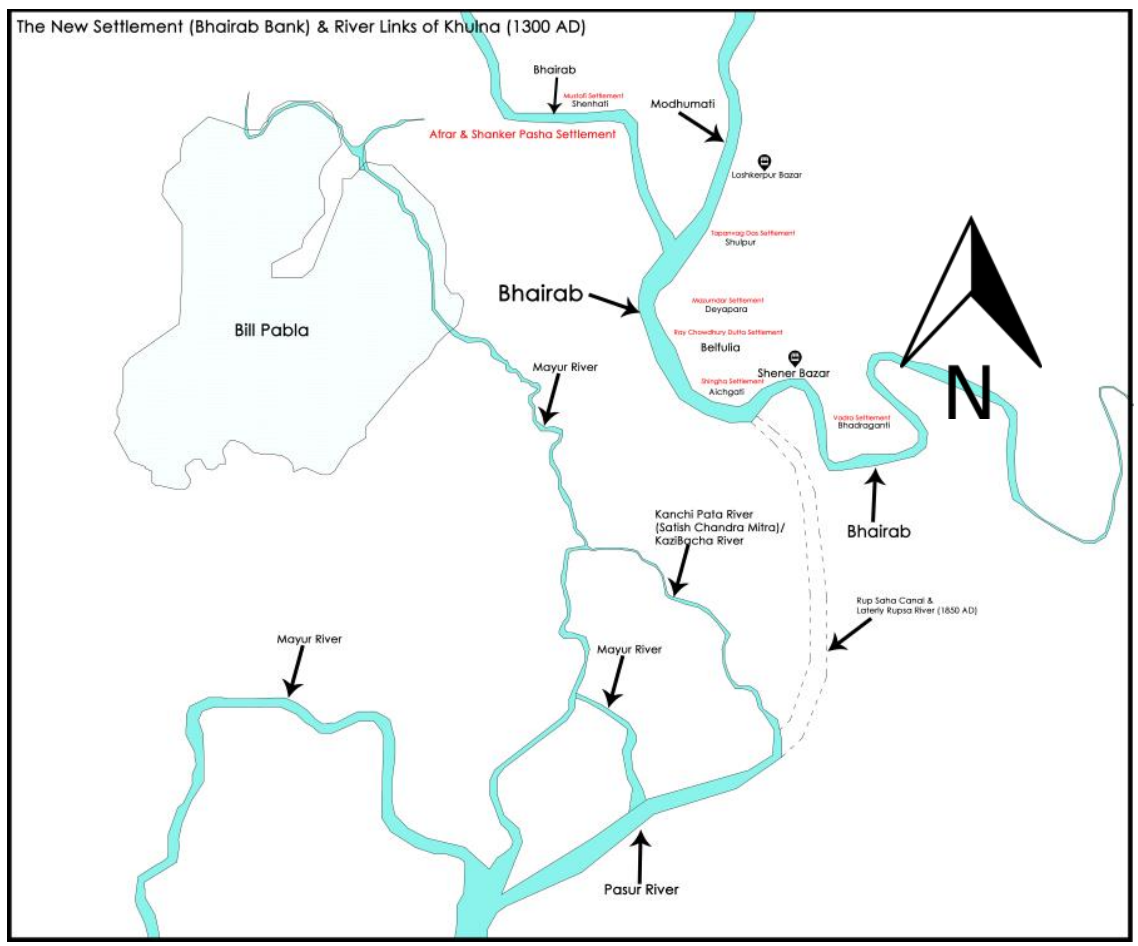

Fig. 02: The settlement map at Bhairab bank according to "Satish Chandra Mitra", Source: Author [2,394-396] 
Socio - Economical Chronology \& Influential Factors for the commercial trend in Ancient Khulna

According to Satishchandra Mitra, the ancient Khulna was a part of Sundarbans. The whole settlement had established by creating new lands by clearing forests.

\begin{tabular}{|l|l|l|}
\hline Timeline & Socio-Economic Ineident & Influential Factor \\
\hline $6^{\text {th }}$ Century BC & $\begin{array}{l}\text { Indo Aryan's River Trade } \\
\text { through Bhairab-Pasur }\end{array}$ & Salt Trade \\
\hline $1^{\text {st }}$ Century AD & $\begin{array}{l}\text { Port Gangarezia, Trade with } \\
\text { Overseas }\end{array}$ & $\begin{array}{l}\text { Boat Building and River \& } \\
\text { Sea Transportation }\end{array}$ \\
\hline $13^{\text {th }}$ Century AD & Settlement on Bhairab Bank & Ups \& Downs of Sundarbans \\
\hline $15^{\text {th }}$ Century AD & $\begin{array}{l}\text { Salt and Agricultural Product } \\
\text { Trade, Higher GDP }\end{array}$ & River Bhairab and Pasur \\
\hline $17^{\text {th }}$ Century AD & Dark Era in Economy & Mugs \& Firingis \\
\hline
\end{tabular}

Fig. 03: Socio-Economical chronology of ancient Khulna [2]

\section{Colonial Regime: Emergence of A new Commercial Center, From Charlie's haat to Barobazar (1757AD-1947AD)}

\section{Indigo Planting \& Charlie's Haat :}

Khulna came under the Company in 1793, when Nizamat was abolished.[3] After coming into the hands of the Company, the East India Company began to see Khulna as a potential field for trade. The British started cultivating cotton, indigo, and sugar.
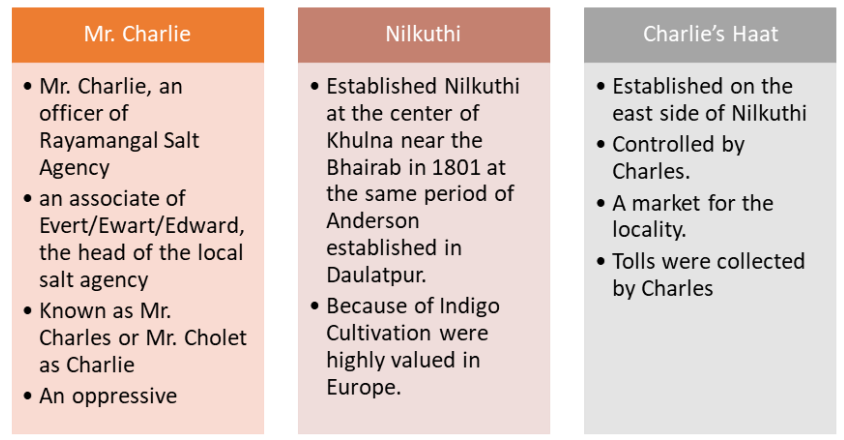

Fig. 04: Evolution of Charlie's Haat [12]

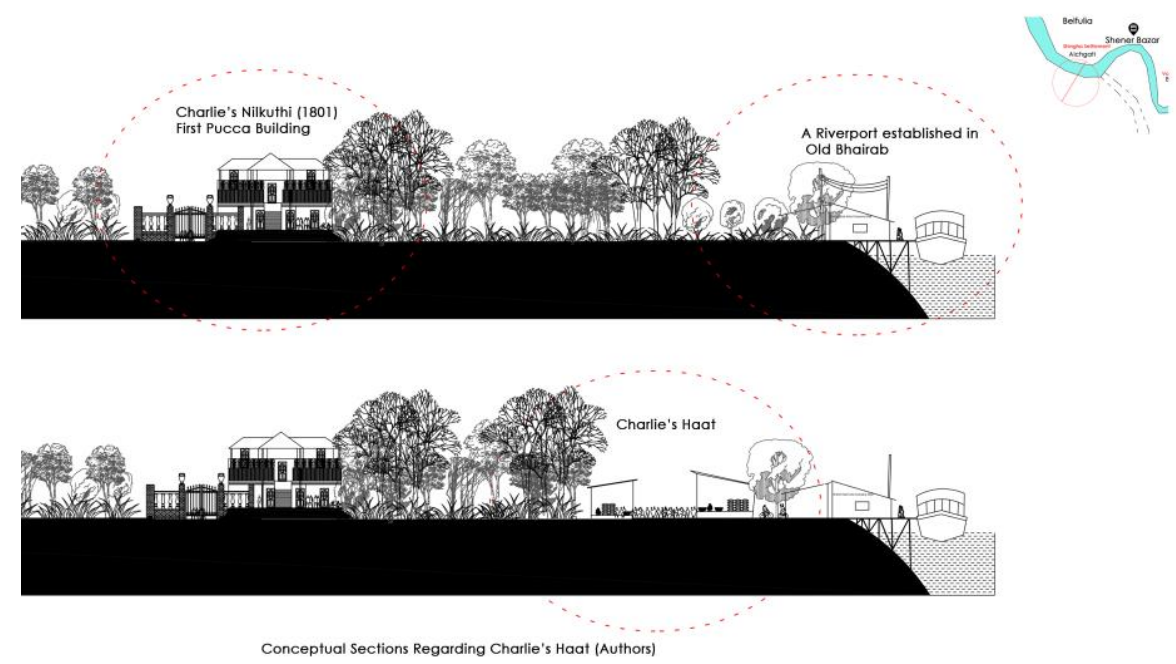

Fig. 05:Conceptual Sections Regarding Charlie’s Haat, Source: Author 
Geographical \& Demographical reason behind establishing the Haat and Nilkuthi: The geographical reason behind the establishment of Nilkuthi was the bend of the old Bhairab river towards Alaipur. At the edge of which was the ancient settlement of Belfulia. The settlement of Belfulia from all other regions, especially Aichgati (on the other side of the Nilkuthi), was significant. Sen's market at Aichgati was one of the oldest markets.[2,394] Some historian thinks that Mr. Charlie of salt agency and the Chollet saheb of the haat was not the same person. Indigo Cultivation was started in Khulna after a decade of establishing Salt Agency (last Quarter of the $18^{\text {th }}$ century).[12,462]

\begin{tabular}{|c|c|c|}
\hline Time Line & Influential Incident & Factors \\
\hline 1766 & $\begin{array}{l}\text { Ship Falmouth sank in } \\
\text { the Pashur River }\end{array}$ & $\begin{array}{l}\text { Culnea / Khulna was first } \\
\text { described in the ship's } \\
\text { documentation }\end{array}$ \\
\hline 1781 & $\begin{array}{l}\text { 'Nayabad Thana' } \\
\text { Established }\end{array}$ & \\
\hline 1781 & $\begin{array}{l}\text { Rayamangal Agency, } \\
\text { established }\end{array}$ & $\begin{array}{l}\text { Salt Trade via Bhairab - } \\
\text { Pasur }\end{array}$ \\
\hline 1791 & $\begin{array}{l}\text { Clash between William } \\
\text { Renee an Indigo planter } \\
\text { and Zaminder Shivnath } \\
\text { Ghosh }\end{array}$ & $\begin{array}{l}\text { The riot of Nilkar vs. } \\
\text { Praja }\end{array}$ \\
\hline 1836 & $\begin{array}{l}\text { a police station named } \\
\text { Nayabad was } \\
\text { established at Talimpur }\end{array}$ & $\begin{array}{l}\text { Rayamangal Salt Chowki } \\
\text { of Koylaghata taken the } \\
\text { responsibility }\end{array}$ \\
\hline 1842 & $\begin{array}{l}\text { Kismat Khulna, Khulna } \\
\text { Subdivision established }\end{array}$ & $\begin{array}{l}\text { First subdivision of } \\
\text { Bengal, established to } \\
\text { control Clashes }\end{array}$ \\
\hline
\end{tabular}

Fig. 06:Influential Factors chronology During British East India Company [2,21]

Historical Influential factors Behind the Commercial State of Khulna: Rayamangal Salt Agency was mentioned that Khulna was once famous for its salt traders. Salt was cultivated in the estuaries of the rivers along the coast. Salt laden boats crowded the shores of Bhairab. However, it was challenging to cross the river and come to the Bhairab river; it took much time. Rupchand Saha, a salt trader, saw that if the canal were cut three miles from the Kazibachha river's mouth to the bend of Bhairab (now the jail ghat), the problem would no longer exist. The name is Roop Saha Khal. Later, the Bhairab stream turned that narrow Saha canal into the Rupsha River.[2,21]

\section{Factors Behind Evolution of Shaheber Haat as Commercial Hub for the Khulna:}

I. Influential Communication System: Four decades after creating the subdivision in 1842, Khulna was turned into a district in 1882. By the 1880s, the Rupsa River (Rup Saha Canal, 1850) created \& established connectivity with the Calcutta. The place had a commercial influence because of agricultural products like cotton, sugar, and later indigo. For this reason, river transportation via boat, as the ancient Khulna introduced. Charlie's haat had renowned as a river port then. [2,21] For this kind of advantage, British Raj was looking for a more significant commercial arrangement. For better navigation before the two years of establishing Khulna as a district, in 1882 introduced Steamer Service. This service was run by the famous "Bengal Central Floatila Company." The steamer ghat was near Charlie's haat / Shaheb's haat called Delta Ghat (Currently a broken Ghat using as godown). Steamer services were running in the route of Khulna - Barishal - Dhacca, and also Khulna-Calcutta. After four years, In the year 1884, the Rail Service had activated. The total length of the rail line was about 110 miles from Khulna to Calcutta. It took $4 \mathrm{hrs}$ to reach. The steamer service for Barishal and Dhaka was linked to this train service. Like, if the train at $9 \mathrm{pm}$ came, then the streamer started. The activation of train services made a groundbreaking change in trade and commerce. In 1918 the RupsaBagerhat Rail-Line had activated. A steamer called Dak Steamer used to travel from Delta Ghat to Rupsa. From a long time ago, Jessore road had connected with Khulna via Fultala, Fulbarigate, BL College, Goyalkhali, and 1 no. Customs Ghat. It was narrow and zigzagged. After establishing the rail, it had extended from Clay road to Joragate. An optional road also had been created at the south of the railway property. This had connected Dak Bangla with Joragate. [2,25] 
II. Arrival of New Traders and the evolution of a larger business center: After the steamer and rail service activation, Charlie's haat turned into a large business center. New people in business, merchants, and traders started to come here from home and abroad. Marwari traders come from Kolkata and adjoining areas. They came to the center of the market and started trading by setting up shops, warehouses, god owns. Attempts are being made to reshape the old and unplanned haat by constructing planned roads to make them suitable for the district town. Gradually, the region became the major commercial and economic center. The old haat become the biggest market in the town, why people started to call it Barobazar means the big market. [12,118]

Evolution in stakeholders, structures of the market place, and land use pattern in the Colonial Period: The evolution of stakeholders, structures of the market place and land use pattern were divided into two phases in the Colonial Period. The phases had created for the power shifts between the British East India Company and British Raj. Another Influential Factor was the river Rupsa which enabled water transportation and made British Raj thinking for a new trade revolution.

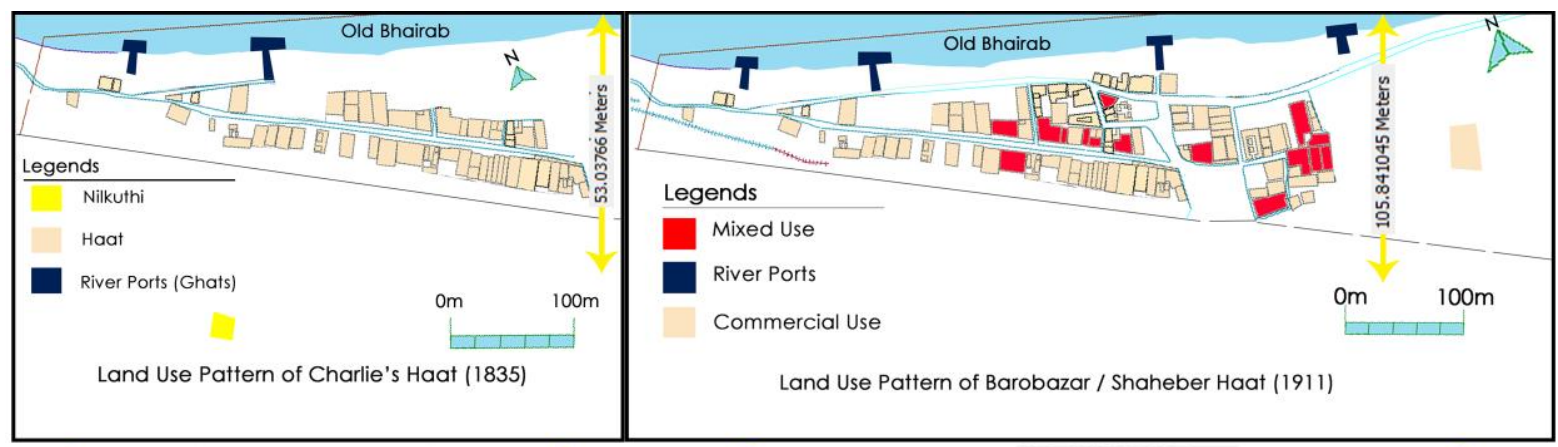

436.805313 Meters

579.815366 Meters

Fig. 07: Changes in Land Use Pattern Between two phases (British East India Company and British Raj), Source: Author

\begin{tabular}{|c|c|c|}
\hline \multicolumn{3}{|c|}{ Comparative Analysis of Evolution } \\
\hline Timeline & 1793-1858 (Company Period) & 1858-1947 (British Raj Period) \\
\hline Stakeholders & $\begin{array}{l}\text { East India Company, Raymangal } \\
\text { Salt Agency, Local People }\end{array}$ & $\begin{array}{l}\text { British Raj, Marwari \& Hindus from } \\
\text { Calcutta, Local People, Khulna } \\
\text { Municipality, BCR, Assam- Bango } \\
\text { Railway, Bengal Central Flotila } \\
\text { Company, Local Zaminder } \\
\text { (Zaminder of Jessore) }\end{array}$ \\
\hline Commercial Style & $\begin{array}{l}\text { Local Market, adjustment with } \\
\text { Nilkuthi }\end{array}$ & $\begin{array}{l}\text { Economical Center, Biggest Market } \\
\text { in the city, Regional trade center }\end{array}$ \\
\hline Structures & $\begin{array}{l}\text { Most of provisional structures, } \\
\text { except Nilkuthi }\end{array}$ & $\begin{array}{l}\text { Pucca Structures, Provisional } \\
\text { Structures }\end{array}$ \\
\hline Land Use Pattern & Commercial & $\begin{array}{l}\text { Commercial and Mixed use, } \\
\text { Community structures }\end{array}$ \\
\hline Tax Receiever & The chief of Nilkuthi (Charlie) & Local Zaminder \\
\hline Transportation & $\begin{array}{l}\text { Boats and River port Services ( } 2 \\
\text { Ghats) }\end{array}$ & $\begin{array}{l}\text { Steamer Services, Rail, Roadway, } \\
\text { River port and Steamer port }\end{array}$ \\
\hline
\end{tabular}

Fig. 08:Comparative Analysis of Evolution in Colonial Period [12,462] 


\section{Trade policies According to Chronology:}

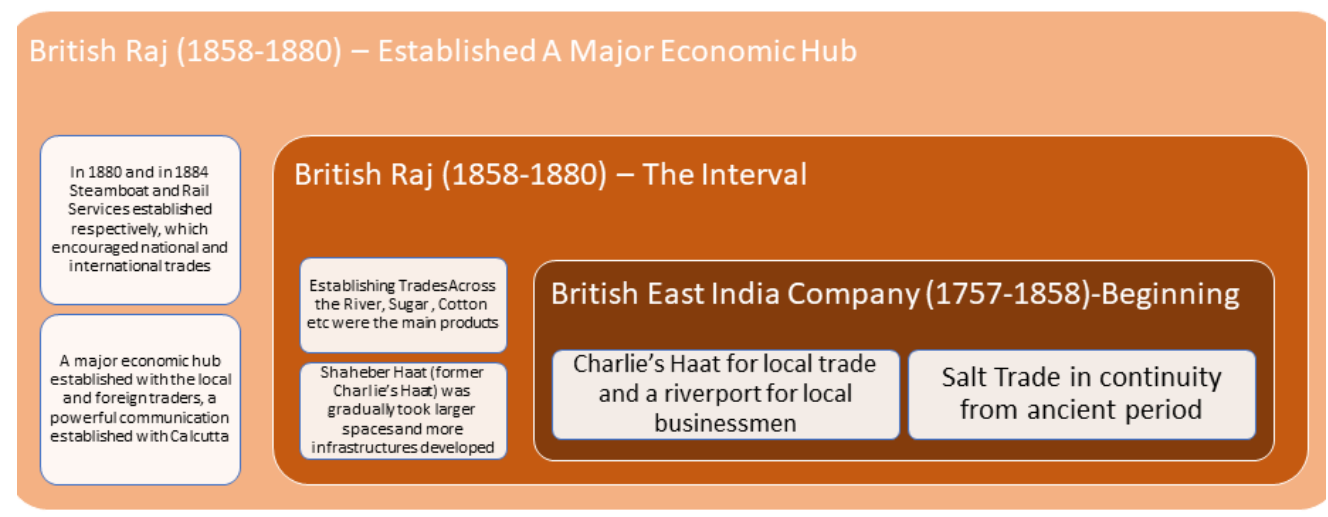

Fig. 09: Trade Policies in colonial regime [2,985]

\section{A massive changes in Owners and Evolution of a new Commercial Trend in Pakistan Period (1947-1971):}

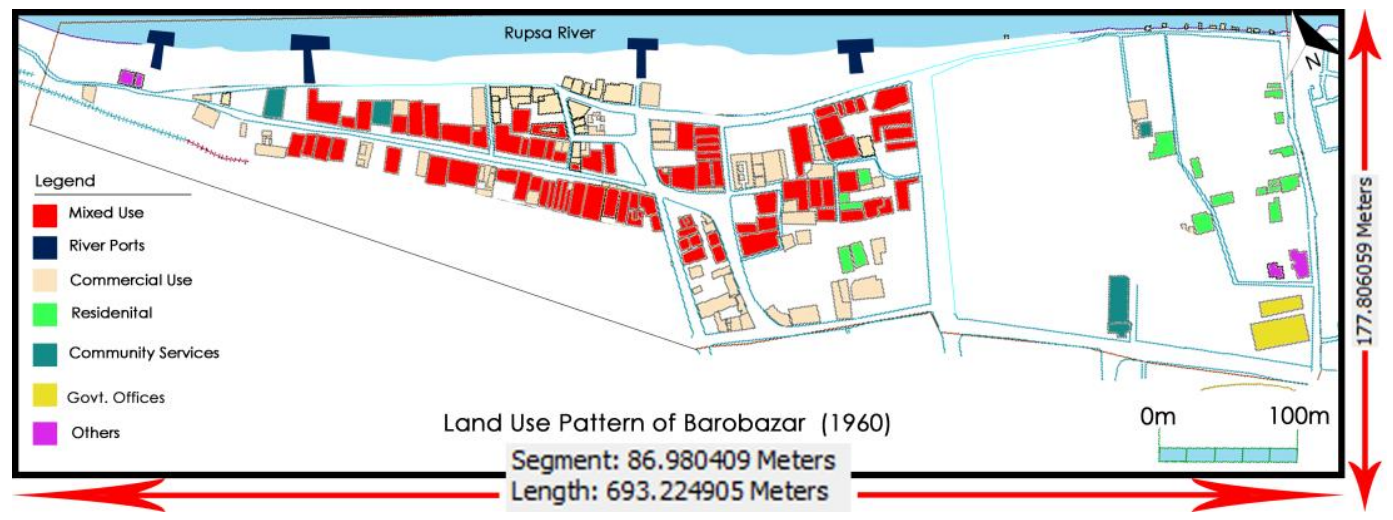

Fig. 10:Infrastructural Map of Economic center of Barobazar in Pakistan Period, Source: Author

During the 1950 s to 1970 s, the trade multiplication effect of rapid industrialization in the Khulna region transformed the social, economic, and urban fabric of Khulna city more like an industrial base than a commercial. (Ahsan,2012) After the division in 1947, Khulna included with the Pakistan partition. Why the rail connection and road connection with Calcutta had shut down. So, most of Hindu and Marowari owner left the country as well; they left the property. East Pakistan had established a new and well communication with East Pakistan. Most of the Punjabi \& Islamia community came here for business purpose. They took over the shops and trades left by the Marwaris and the Hindus. After 1947 as a new force called EPR (East Pakistan Rifles) was established, the property started to use as EPR colony. Those were thatched huts. The main marketplace almost remained the same as it was in Colonial Regime. Many mosques were also established there. They extended a little portion of the market. The steamboat service also had activated in that Period with delta ghat. In 1964 KDA (Khulna development Authority) established and influenced the rapid urbanization, which played an important role for Barobazar and Dakbangla to be an economic zone and city center. In 1960, Jessore Road was straightened in a new way. As a result, it merges directly with Dakbangla. This further accelerated business communication.[13,162] Although the Bazar portion was almost the same, a new commercial zone and mixed-use zone were also developed. Some official buildings, banks, residential hotels, and residential infrastructure development in the southeast portion of the main market. Some secondary roads also had developed in this Period for communication purposes. The whole development pattern encouraged Barobazar as the central economic zone and the city center. These commercial developments between the 1950s and 1970s 
influenced Barobazar to be the southern region's major economic hub in the late 90s. After the 1950s, according to the Land Rights Act, the market is auctioned off and leased. These tenants used to collect money as they wished. This system has been changed after the liberation war. [12,462]

\section{Bangladesh Period (1971-till today) :}

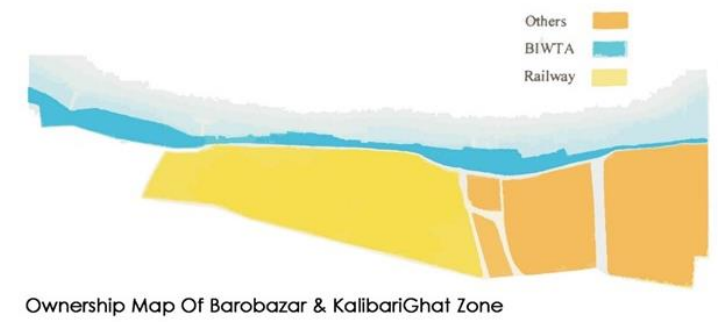

Ownership Map Of Barobazar \& KalibariGhat Zone

[Source: Investigating Socio-Spatial Dynamics of Encroaching Urban Waterfront: A case of Boro Bazar along Rupsa-Vairab River-Belt, Khulna , Partial Requirements of MSc in Human Settlement Thesis by Mahmudul Hasan Bhuiyan, Khulna University]

Fig. 11: Source: Mahmudul Hasan Bhuiyan (2018)[15]

After the liberation war, the commercial sail of the Barobazar took a new breath. As the importance of Khulna as a district town and a major commercial city increased, so did the expansion and importance of the Barobazar. The changing city form gave Boro Bazaar the shape of a mixed-use zone rather than solely a commercial or business zone. The international highway between India and Bangladesh, the divisional highways, railways, and inter-district waterways crossing over Boro Bazaar and their trade links makes it highly potential and important for national and international trade and commerce. (Ahsan,2012). In the after-liberation war period, most Pakistani people went to their country by selling their business to the local people. Thus how after 71, the local people gradually took part in commercial and industrial trade. A lot of small cottage industries developed in this Period. A rapid transformation happened to create a new trade class division. Besides, a nationalist political influence in 80 s, created definite trade policies and classes. The socio-political scenario also impacted the economy. In 1984 Khulna achieved the rank of a divisional city as well as Khulna City Corporation Established. A new wholesale and retail market (Khwaja Khan Jahan Ali Hawkers' Market) was also had established. In 1985, because of the construction of the new station road and infrastructural development. Some godowns and mills had shifted to the railway property, which was previously EPR Colony. Several oil and masala mills, godowns, Wholesale shops, goldsmith shops, and residential development occurred across the vacant lands. New official Buildings developed across the Sir Iqbal road from Thanar Mor to Kalibari Ghat. As the existence of the dam protecting the city is almost disappearing, from the last 50 years, temporary structures built at the bank of Rupsa. Which are using for wholesale and retail shops, wholesale shops, and godowns. In 1972, a committee was formed under the supervision of the Hat Bazar by an order called Hat-Bazar system to remove the problems related to the lessee. Toll was collected through a youth cooperative. However, due to land ownership by various institutions such as Railway Corporation, BIWTA, City Corporation, and private ownership, tolls are collected in different ways. For example, the city corporation collects revenue from the railways on the land owned by the railways. Individually owned property is leased individually, and many disputed properties are still in the DC office and privately owned inter-conflict. [12,462]

\section{The Existing Land Use Pattern of Borobazar in 2o2o:}

As the population of Khulna increased, so the density of Barobazar also increased tremendously. In the current situation, Barobazar stood in a condition where there is no vacant land and faced an unplanned development, which creates a massive haphazard situation in Market Place. Though the southern part of Barobazar is a little bit messy but over-all, it faces so many problems in spatial management. Here we have surveyed the whole Barobazar marketplace, market places from clay road, 
and official areas at sir Iqbal road to the later developed residential zone at the south. This will give a clear idea regarding the development pattern of a mixed-use zone from the commercial zone and an economic hub's development, the existing condition created from rapid urbanization, which was influenced by Barobazar. Moreover, finally, this survey will direct to the policies of Urban Regeneration.

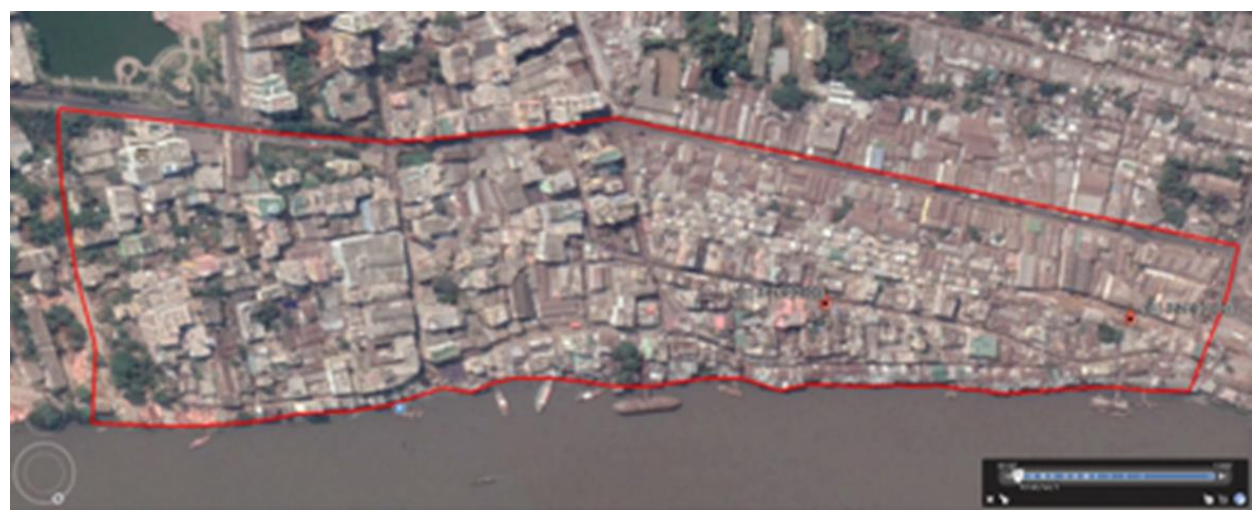

Fig. 12:Study Area: Barobazar \& Kalibari Ghat Zone, Source: Google Earth Pro

Land-Use Pattern: Although there is a high financial flow in Barobazar due to multiple actor encroachment, rapid urbanization, Political influences made Barobazar a zero vacant land zone. The structural density is so high that there has occurred a different kind of land tenure. Some have been possible due to land grabbing, the river-belt possession. Hawkers' grabbed the footpath and also the cover drain . The occupancy map of 2020 depicts the haphazard situation of Barobazar as well Kalibari Ghat zone.

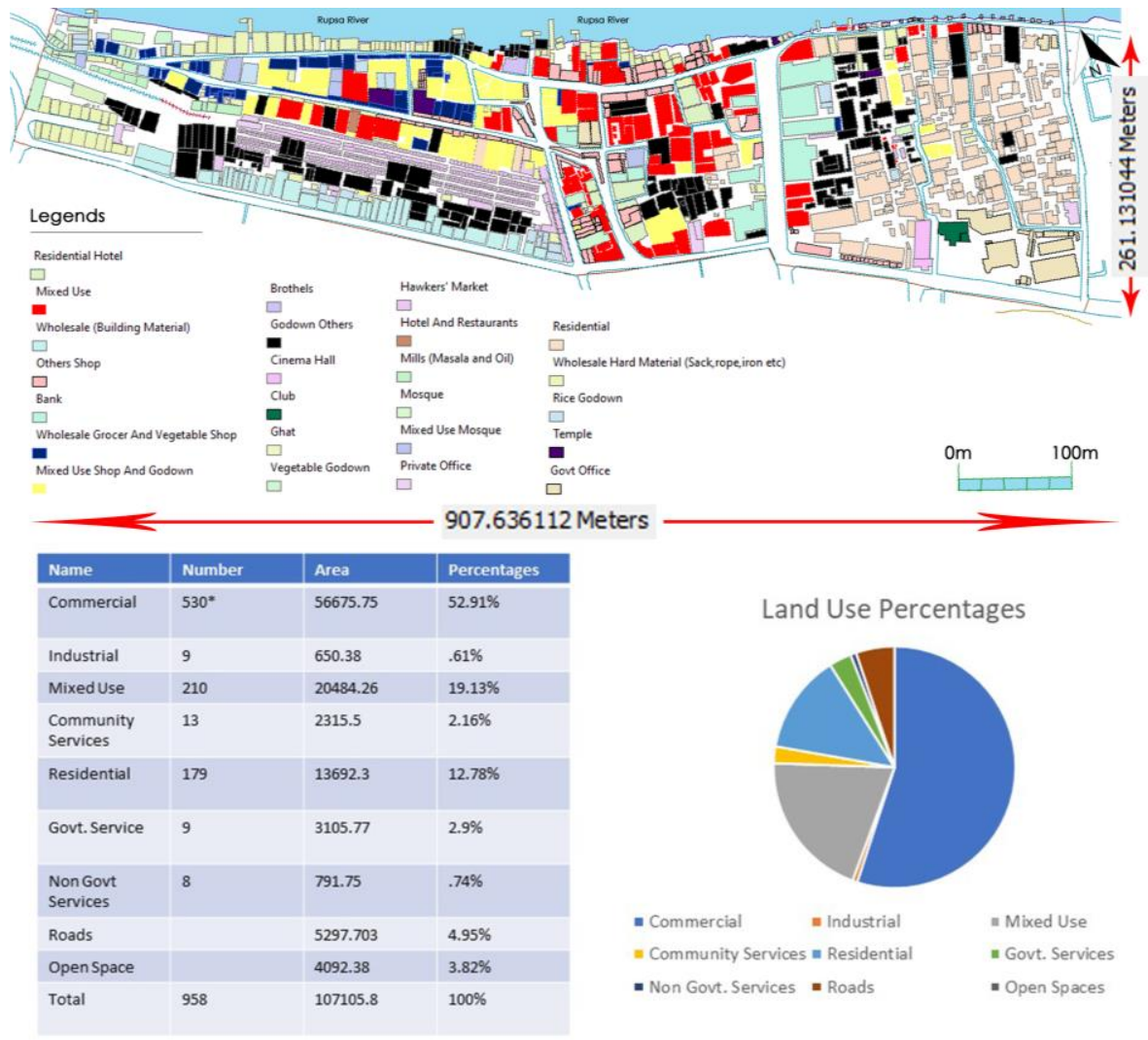

Fig. 13:Occupancy Map of Barobazar \& Kalibari Ghat Zone, 2020, Source: Author 


\section{Infrastructural Condition:}

In recent years, a massive number of Pucca buildings has developed due to economic expansion. But due to the breach of the city protection dam, a lot of temporary structures also have been developed in the last $4 / 6$ decades.

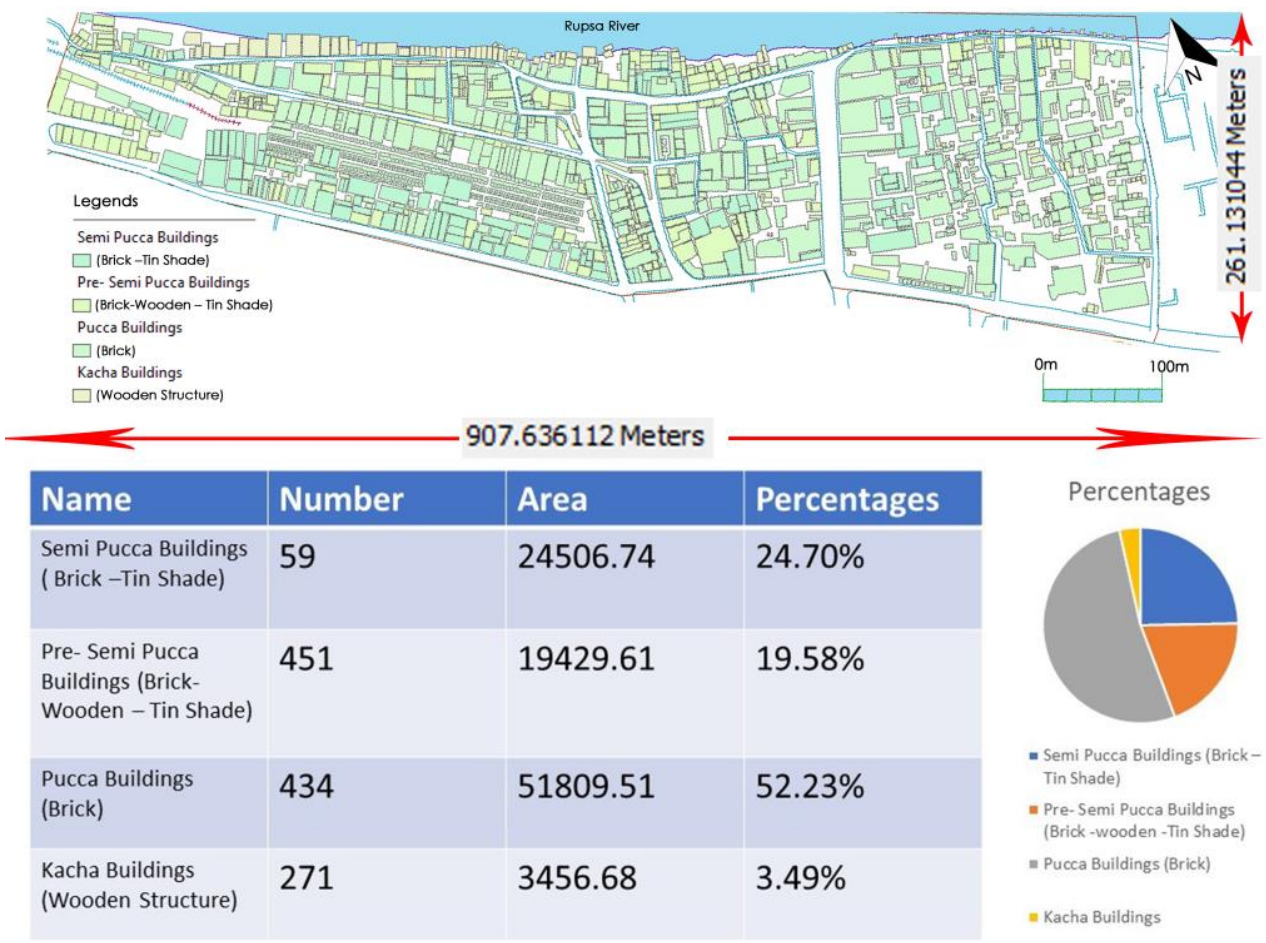

Fig. 14:Structural Map of Barobazar \& Kalibari Ghat Zone, 2020,Source:Author

\section{Existing Commercial Condition In 2020:}

Barobazar has already developed its infrastructure in an unplanned state, not just in an unplanned economic expansion. Needless to say, as the number of small cottage industries and mills has increased in the last 15 years, so has the amount of vacant space. However, due to the sharp decline in such economic activities, it cannot be said that the standard of living is going down. Land grabbing, the prospect of higher profit jumps, and disputed property are hindering new thinking about the big market's development pattern. The occupation of the banks of the Rupsa river, the temporary shops, and the sidewalks' occupation by hawkers all indicate this.

\section{The Flow of Commercial Evolution Establishing the Missing Link Between Eras:}

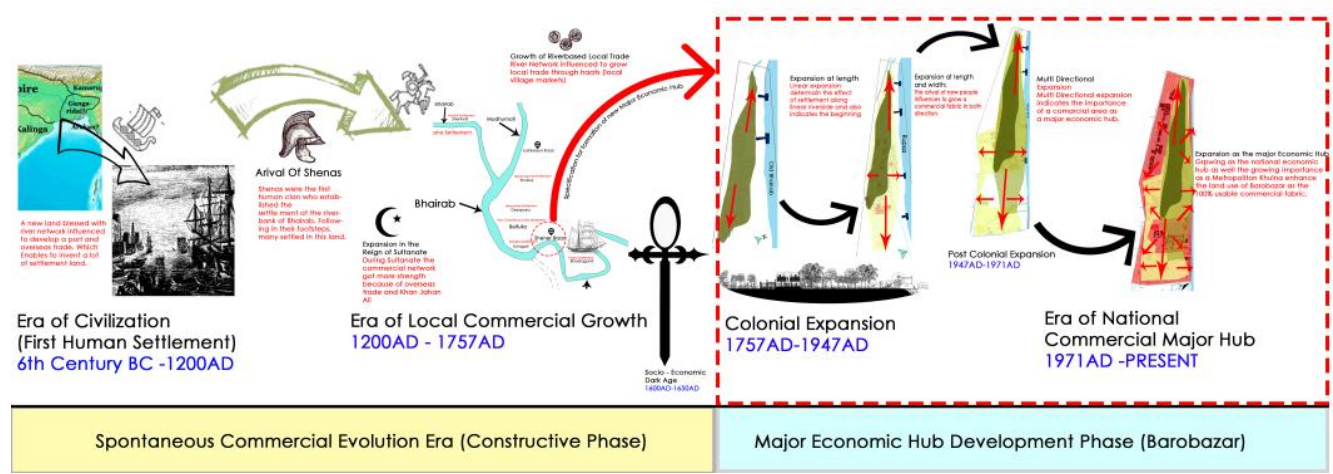

Fig. 15: Chronological Flow of Commerial Evolution,Source:Author

\section{Research Opportunities:}


As the center of the heart of Khulna city, Barobazar has developed in a spontaneous and unplanned way. There were so many missing links to its evolution and growth. Many data were not available on why the revitalization and proper development of Barobazar was a myth. This paper tried to enhance that opportunity for further research about Barobazar in the near future.

\section{Conclusion:}

Whether it is geographical or political, the Khulna region's economic importance and backbone have been built since ancient times, although scattered trade activities have been going on since ancient times or there was an expansion of local trade for local settlements; nevertheless, it must be said that Khulna was so vital that it was behind this ancient trade. This is because Bhairab has been navigating since the expansion of the salt trade in ancient times. As a result, the Rayamangal Salt Agency started its journey in the Colonial Period. As a result, the construction of a river port on the banks of the Bhairab, the digging of the canal by the salt merchant Rup Saha and the establishment of Charlie's Hat are all part of this. In the end, its commercial evolution is responsible for the emergence of today's Barobazar as the largest marketplace in the southwestern part of Bangladesh, or as a central economic hub. Everything has expanded, the economy has recovered, new institutions have sprung up, but at the end of Barobazar's thousand-year history, today's commercial land use pattern is deplorable. The trend analysis of the last century tells us the cause of this condition. This research of evolution and trend will play an essential role in the revitalization and regeneration of Barobazar and will guide future research regarding Barobazar.

\section{References:}

01. A. F. M Abdul Jalil: History of the Sundarbans, p. 557.

02. Jessore -Khulnar Itihas ( The History of Jessore \& Khulna) by Satish Chandra Mitra - $1^{\text {ST }}$ \& Second Part 1335 Edition

03. Hunter, William Wilson (1908). Imperial Gazetteer of India. Oxford, UK: Oxford University Press. p. 287.Narayanan, N. P., (2012). Urban Voids \& Shared Spaces. Retrieved September 13, 2015, from https://nipppo.wordpress.com/2012/05/07/urban-voids/

04. http://www.thomaslessman.com/History/images/East-Hem 323bc.jpg

05. Tapan Raychaudhuri; Irfan Habib, eds. (1982). The Cambridge Economic History of India. Volume I, c.1200-c.1750. Cambridge University Press. p. 130. ISBN 978-0-521-22692-9

o6. María Dolores Elizalde; Wang Jianlang (6 November 2017). China's Development from a Global Perspective. Cambridge Scholars Publishing. pp. 57-70. ISBN 978-1-5275-0417-2

07. Sushil Chaudhury (2012). "Trade and Commerce". In Sirajul Islam and Ahmed A. Jamal (ed.). Banglapedia: National Encyclopedia of Bangladesh (Second ed.). Asiatic Society of Bangladesh

o8. Rila Mukherjee (2011). Pelagic Passageways: The Northern Bay of Bengal Before Colonialism. Primus Books. p. 30. ISBN 978-93-80607-20-7.

09. Irfan Habib (2011). Economic History of Medieval India, 1200-1500. Pearson Education India. p. 185. ISBN 978-81-3172791-1

10. Investigating Socio-Spatial Dynamics of Encroaching Urban Waterfront: A case of Boro Bazar along Rupsa-Vairab River-Belt, Khulna , Partial Requirements of unpublished MSc in Human Settlement Thesis by Mahmudul Hasan Bhuiyan , Khulna University

11. Shamima, A. (2005). Regulatory involvement and the problems in urban markets: a case study of Boro Bazaar in Khulna city. Unpublished BSc. Urban and Rural Planning, Khulna University, Khulna

12. Khulna Jelar Itihash- AFM Abdul Jalil

13. Shree Khagendranath Basu: MaheshwarPasha Porichoy, First Edition- Ashar 1336 